\title{
AGRICULTURE LAND PRICE SETTING SYSTEMS, AND POSSIBLE DIRECTIONS FOR THEIR UPDATING
}

\author{
Josef Slaboch ${ }^{1}$, Michal Malý ${ }^{1}$ \\ ${ }^{1}$ Department of Economics, Faculty of Economics and Management, Czech University of Life Sciences Prague,
}

Link to this article: https://doi.org/10.11118/actaun.2021.058

Received: 14. 10. 2021, Accepted: 30. 11. 2021

To cite this article: SLABOCH JOSEF, MALÝ MICHAL. 2021. Agriculture Land Price Setting Systems, and Possible Directions for Their Updating. Acta Universitatis Agriculturae et Silviculturae Mendelianae Brunensis, 69(6): 655-664.

\begin{abstract}
The aim of this article is to assess the effect of the applied land valuation system on the price of land, and as a consequence of the implied links to compare the valuation of soil units in Slovakia and the Czech Republic. In order to fulfil this objective, an econometric approach was chosen in the form of a hedonic price model, whereby the heteroscedastic corrected linear regression model was specifically applied. The estimated model shows a very high explanatory ability, together with a high parametric significance for most fictitious variables (land characteristics), and at the same time also fulfils the theoretical and logical consistency of general assumptions. From the results, it is evident that, in the case of Slovakia, ESEU [evaluated soil ecological unit] valuation is affected primarily by the climatic region and the main soil unit. When comparing the results of the effect of individual input factors on the price of land in the Czech Republic and Slovakia, it can be stated that the results are slightly different in the effect of certain factors. The characteristics of soils located in warm climatic regions with a valuable soil type of chernozem and low slope are significant and positively intensive factors.
\end{abstract}

Keywords: soil, land price, hedonic price, land policy, evaluated soil ecological unit

\section{INTRODUCTION}

Soil is the uppermost porous layer of the Earth's solid crust, which is composed of mineral particles of various sizes, living organisms and dead remains, and at the same time is permeated by water and air (Ministry of the Environment, 2020). From an economic perspective, soil is an unpropagable production factor, which moreover is decreasing perceptibly over time due to population growth, inappropriate human activity and other determinants, including natural ones; unfortunately, this applies both on a global scale and for the Slovak Republic, see for example Bujnovský and Vilček (2011). It is therefore more than evident that, from a long-term perspective, the situation will very likely deteriorate as the demands for production for a significantly growing population increase in disproportion to the decrease in acreage, particularly that of agricultural land, see for example Schneider et al. (2011). Together with the discussion about measures caused by geoclimatic changes, this general trend, which is evident on a global scale, should also bring about a change in the approach to basic production factors - water and soil. Both of the afore-mentioned factors are relatively closely interlinked, and care for them should be a basic priority for society and one of the pillars of economic policy. One of the indicators of the approach to soil, particularly on a national level, are the different land valuation systems, which may have a basic meaning in the form of the setting of a uniform land price, but the mechanism varies significantly. Differences can be seen not only in the form of land price definition, but also in the very principle of determining the given result, and in particular the breadth of the 
determinants that are included in the mechanism. Under the conditions of Central Europe (e.g. the V4 countries), it is possible, in principle, to encounter two simultaneously applied land valuation systems, being the classic market method based on the creation of a market price by supply and demand in the submarket, and an artificial approach which is based on a system of exhaustively defined soil factors that affect the resulting value, but which are not uniformly geopolitically set, which leads to relatively interesting differences in land prices, and it therefore makes sense to perform a comparison of the afore-mentioned systems with the aim of objectifying the included determinants. In the Slovak and Czech Republic, the afore-mentioned valuation system mainly reflects the qualitative aspects of soil expressed using soil ecological units, which makes the system almost completely exhaustive and relatively simple for setting the land price, but the given systems do not take into consideration other functions that land can (and in many areas even must) fulfil from a national economic perspective. Another very interesting area is the expansion of determinants to include socioeconomic factors, while valuing public goods arising from land, which Nigmann et al. (2018) analyse across EU states, and thereby also offer directions for the updating of the conceived systems so that they pay more attention to the social and environmental aspects of land. Another (completely different) method, based on a significantly different foundation of fuzzy systems, is offered by Kilič et al. (2019).
As was already mentioned above, soil quality, and thereby also yields, is mainly determined by soil fertility, which is the main prerequisite for agricultural production. In the Slovak and Czech Republic, a comprehensive soil survey (CSS) was conducted, which represented the coordination of two basic areas, being a soil science land survey (1960-1970), together with a system of agronomic topsoil research for the purpose of ascertaining the situation regarding available nutrients, soil reactions and liming requirements (Němec, 2001). The actual rating of the agricultural land fund took place in the 1970s. The aim of the rating was the assessment and economic valuation of all decisive factors in the given territory (primarily climate, relief, soil unit), with differences in production and cost assumptions regarding agricultural land. The basic components of the rating are the rating classification system, and the economic characteristics of all its units, whose interconnection enables the creation of a set of economic indicators in a unified rating information system (Klečka et al., 1984). The evaluation of the productive capacity of the land is based on an evaluation of the difference in the effectiveness of deposits in the land under specific conditions - it is a derivation of the cost of parameterized production in relation to parameterized costs (Němec, 2001). A basic unit - ESEU - was created for the purpose of rating agricultural land. This unit represents a production potential evaluation system, based on several parameters.

\begin{tabular}{|c|c|c|c|c|c|c|}
\hline $\begin{array}{c}\text { Region } \\
\text { code }\end{array}$ & Characteristics & 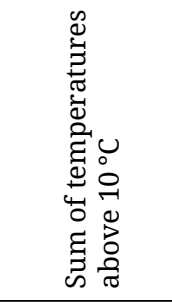 & 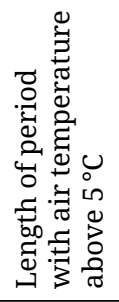 & 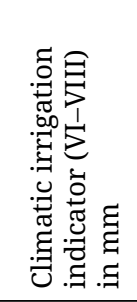 & 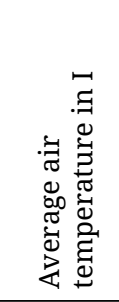 & 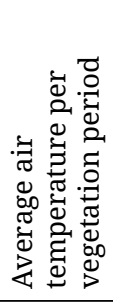 \\
\hline 00 & Very warm, very dry, lowland & Above 3,000 & 242 & 200 & -1 to -2 & $16-17$ \\
\hline 01 & Warm, very dry, lowland & $2,800-3,000$ & 237 & $150-200$ & -1 to -3 & $15-17$ \\
\hline 02 & Sufficiently warm, dry, hilly & $2,500-2,800$ & 231 & $100-150$ & -1 to -3 & $15-16$ \\
\hline 03 & Warm, very dry lowland, continental & $2,800-3,160$ & 232 & $150-200$ & -3 to -4 & $15-17$ \\
\hline 04 & Warm, very dry, basin, continental & $2,800-3,030$ & 229 & $100-200$ & -2 to -4 & $15-16$ \\
\hline 05 & Relatively warm,, dry, basin continental & $2,500-2,800$ & 222 & $100-150$ & -3 to -5 & $14-15$ \\
\hline 06 & Relatively warm, slightly dry, highland, continental & $2,500-2,800$ & 224 & $50-100$ & -3 to -5 & $14-15$ \\
\hline 07 & Slightly warm, slightly humid & $2,200-2,500$ & 215 & $0-100$ & -2 to -5 & $13-15$ \\
\hline 08 & Slightly cold, slightly humid & $2,000-2,200$ & 208 & $0-100$ & -3 to -6 & $12-14$ \\
\hline 09 & Cold, humid & $1,800-2,000$ & 202 & $50-60$ & -4 to -6 & $12-13$ \\
\hline 10 & Very cold, humid & Below 1,800 & 182 & Below 50 & -5 to -6 & $10-11$ \\
\hline
\end{tabular}

Source: author's work by Džatko and Sobotská et al. (2009) 
In the Czech Republic, the ESEU is composed of a 5-digit numerical code, which states the climatic region, main soil unit, land slope, directional orientation, and last but not least soil profile depth and skeletality (VÚMOP, 2020). Climatic regionalisation is very important for rating purposes, because agricultural crop yields depend primarily on temperature and moisture (Mašát et al., 2002). The ESEU system currently contains 2,278 codes. In Slovakia, it's based on the same soil science land research. Originally, the ESEU code was the same as in the Czech Republic (it was a 5-digit numerical code). A significant change in the coding took place in 1996. The essence of this change was the extension of the original code, whereby the ESEU is currently composed of a 7-digit numerical soil property code. The first two digits stand for inclusion in the given climatic region (see Tab. I), while the following digits indicate the main soil unit code (codes 00-99, which due to spatial reasons are not listed in the article; for more information, see Džatko and Sobotská et al. (2009).

This is followed by a digit indicating slope and exposure (0-9), another digit for skeletality and soil profile depth (0-9), and a last digit which indicates soil granularity (1-5); see Tab. II.

The soil granularity categories are specific only for Slovakia, whereby they are based on the new granularity classification scale according to the fine earth fraction content (soil particles smaller than $0.01 \mathrm{~mm}$ ): sandy soils $0-10 \%$, loamy sand 10-20\%, sandy loam 20-30\%, loam 30-45\%, clay loam $45-60 \%$, clayish $60-75 \%$ and clays over $75 \%$. Granularity indicates the granularity of the topsoil, or more precisely the surface humus horizon.

\section{MATERIALS AND METHODS}

The aim of the performed study is to evaluate the effect of the applied land valuation system on the price of land and, as a result of the implied links, to compare soil unit valuation in the Slovak and Czech Republic, i.e. to determine significant and probably excessive valuation system determinants, which could indicate possible directions for modifying the valuation system in the future. At the same time, the results of the model can be understood as shadow prices of the given input parameters. For these purposes, it is advisable to generate a quantitative tool for estimating the price of land depending on the determinants of the land valuation system. The afore-mentioned system must be sufficiently robust to be able to cover a very wide scale of valuation system components, and at the same time to enable the identification and specification of different parameters in the valuation system in the Slovak and Czech Republic. For example, Dirgasová et al. (2017) strove for conception within the scope of the market price setting mechanism under the conditions in the Slovak Republic, but for the official land price system and when taking into consideration the afore-mentioned requirements, a different econometric approach was chosen in the form of a hedonic price model, which specifically involved the application of the heteroscedastic corrected linear regression model, whose basic specification for the Slovak Republic corresponds to the following relationship No. 1:

$L P_{i}=f(C R, M S U, S L O, E X P, S K E, S D, T E X)$

where

$L P_{i} \ldots \ldots . . . . i s$ a land price of $\mathrm{ESEU}\left(\mathrm{SK} / \mathrm{m}^{2}\right)$,

$C R$........represents the vector of dummy variables for the characteristics of the climate region,

$M S U$....is a vector of dummies for the main soil unit,

II: Other characteristics of the ESEU code

\begin{tabular}{|c|c|c|c|c|c|}
\hline Code & $\begin{array}{c}\text { Slope } \\
\text { and orientation }\end{array}$ & Exposure & Skeletality & Soil depth & $\begin{array}{c}\text { Granularity } \\
\text { (Slovak Republic only) }\end{array}$ \\
\hline 0 & $\begin{array}{l}\text { Completely flat: } \\
\text { 0-1 degrees }\end{array}$ & $\begin{array}{l}\text { Flat land with } \\
\text { omnidirectional exposure }\end{array}$ & $\begin{array}{l}\text { With admixture } \\
\quad \text { to } 10 \%\end{array}$ & $\begin{array}{l}\text { Deep soil: } \\
\text { over } 60 \mathrm{~cm}\end{array}$ & \\
\hline 1 & $\begin{array}{c}\text { Flat: } \\
\text { 1-3 degrees }\end{array}$ & Southern exposure & $\begin{array}{l}\text { Slightly gravelly, stony: } \\
10-25 \%\end{array}$ & $\begin{array}{l}\text { Medium depth soil: } \\
\text { 30-60 cm }\end{array}$ & $\begin{array}{l}\text { Light soils } \\
\text { (sandy and loamy sand) }\end{array}$ \\
\hline 2 & $\begin{array}{l}\text { Slight slope: } \\
\text { 3-7 degrees }\end{array}$ & $\begin{array}{l}\text { Eastern and western } \\
\text { exposure }\end{array}$ & $\begin{array}{l}\text { Stony: } \\
25-50 \%\end{array}$ & $\begin{array}{l}\text { Shallow soil: } \\
\text { to } 30 \mathrm{~cm}\end{array}$ & $\begin{array}{l}\text { Medium-heavy soils } \\
\text { (loam) }\end{array}$ \\
\hline 3 & $\begin{array}{l}\text { Medium slope: } \\
\text { 7-12 degrees }\end{array}$ & Northern exposure & $\begin{array}{l}\text { Very gravelly, stony: } \\
\text { over } 50 \%\end{array}$ & & $\begin{array}{l}\text { Heavy soils } \\
\text { (clay loam) }\end{array}$ \\
\hline 4 & $\begin{array}{l}\text { Significant slope: } \\
\text { 12-17 degrees }\end{array}$ & & & & $\begin{array}{l}\text { Very heavy soils } \\
\text { (clayish and clays) }\end{array}$ \\
\hline 5 & $\begin{array}{l}\text { Steep slope: } \\
\text { 17-25 degrees }\end{array}$ & & & & $\begin{array}{l}\text { Medium-heavy soils } \\
\quad \text { (sandy loam) }\end{array}$ \\
\hline 6 & $\begin{array}{l}\text { Precipice: } \\
\text { over } 25 \text { degrees }\end{array}$ & & & & \\
\hline
\end{tabular}

Source: author's work by Džatko and Sobotská (2009) 
SLO .....is a vector of dummies for the land slope, EXP .....is a vector of dummies for the exposure,

$S K E$......represents a vector of dummies for the skeletality,

$S D$........is a vector of dummies for the soil depth and

TEX .....is a vector of dummy variables representing the soil texture.

The composition of the variables, or more precisely the content of the model, necessarily implies the above-characterised soil evaluation system according to evaluated soil ecological units (ESEU) in the Slovak Republic. The particular specification and content of variables is based on the official classification of the VÚPOP (Soil Science and Conservation Research Institute) information service, where the ESEU handbook (compiled by Džatko and Sobocká et al., 2009) is available. Based on the stipulated ESEU codes (see the handbook), their decomposition into individual input factors affecting ESEU valuation took place. Information was therefore created for every code that stated inclusion in climatic region, main soil unit, slope, exposure, skeletality, soil profile depth and last but not least granularity. The decomposition of information combining two factors in one number took place according to Džatko and Sobocká et al. (2009) and precisely according to table no. 7 (pages 40-42).

As stated above, to achieve the main goal we will apply a heteroscedastic corrected linear regression model (1) in the form of a hedonic price model Therefore, it was necessary to define derived dummy variables that will fulfil the prerequisites of the hedonic model, and whose values will respect the ESEU unit mechanism in the Slovak Republic. The detailed variable specification is provided in Tab. III.

The applied data for the estimate of the conceived model was obtained from the publicly available

III: Model variable specification

\begin{tabular}{lcc}
\hline \multicolumn{1}{c}{ Variable } & Specification & Dummy variable \\
\hline CR & climate region & DCR_0-10 \\
MSU & main soil unit & DMSU_0-99 \\
SLO & slope & DSLO_1-6 \\
EXP & exposure & DEXP_0-3* \\
SKE & skeleton & DSKE_0-5 \\
SD & soil depth & DSD_0-3 \\
TEX & texture & DTEX_0-5 \\
LP & land price & \\
\hline
\end{tabular}

Source: author's work

Note: * exposure does not contain the value "2" data set of the Ministry of Agriculture of the Slovak Republic, which is based on Regulation of the Ministry of Agriculture of the Slovak Republic no. 38/2005 Z. z. (MP SR, 2021). The database contains a total of 6,962 classification units with an assignment of an adequate land price ${ }^{1}$, which enables a standardised estimate of the model.

Furthermore, for comparison purposes, it is appropriate to mention the basic differences in the land valuation system in the Slovak and Czech Republic. Both valuation systems come from the same comprehensive soil research. In the process, however, there are minor differences between the two systems. If we proceed gradually, according to the individual factors from which the ESEU code is composed, it is evident that the first difference arises in the case of climatic regions. In both systems, climatic regions are defined by several basic characteristics - the sum of temperatures above $10^{\circ} \mathrm{C}$ (same for both systems); furthermore, average temperature, average precipitation, probability of dry vegetation periods and moisture certainty in vegetation periods are used in the Czech Republic. Apart from the sum of temperatures above $10^{\circ} \mathrm{C}$, the following additional characteristics are used in Slovakia: Length of period with air temperature above $5^{\circ} \mathrm{C}$, Climatic irrigation indicator (VI-VIII) in $\mathrm{mm}$, Average air temperature in January and Average air temperature per vegetation period (IV-IX). From the perspective of main soil units, a significant difference is evident in their number. 78 main soil units are defined for these purposes in the Czech Republic, while 99 are defined in Slovakia. Other characteristics for ESEUs are the same in both countries. These are slope, directional orientation, skeletality and soil profile depth. The last difference in the Slovak ESEU system is the listing of soil granularity according to a classification of 1-5, which is not present in the Czech system.

\section{RESULTS AND DISCUSSION}

Tab. IV illustrates the results of a hedonic price model estimate for the Slovak Republic, whereby the output contains an estimate of all dummy variable parameters, together with information regarding their significance. A corrected heteroscedasticity estimator was used to achieve this, because the primary linear regression model estimate contained heteroscedastic errors.

Before the evaluation of the subparameters of the estimated model, it is appropriate to also briefly draw attention to the basic statistical properties of the entire model. According to Tab. V, it is evident that $\mathrm{R}^{2}$, expressing the degree of concord of the model with the data, is at a high level, by which

1 According to Regulation of the Ministry of Agriculture of the Slovak Republic no. 38/2005 Z. z., basic land valuation must be stated in Slovak crowns, which however is no obstacle to the model's properties or its evaluation, and therefore conversion to the present-day currency, the euro, was not carried out. 
IV: Hedonic price model estimate, heteroscedasticity-corrected, using observations 1-6962

\begin{tabular}{|c|c|c|c|c|c|c|c|c|c|}
\hline Variable & Coefficient & Std. Error & $\mathrm{p}$-value & & Variable & Coefficient & Std. Error & $\mathrm{p}$-value & \\
\hline DCR_0 & 1.20378 & 0.277341 & $<0.0001$ & $* * *$ & DMSU_54 & 0.312691 & 0.251401 & 0.2136 & \\
\hline DCR_1 & 1.02986 & 0.274849 & 0.0002 & $* * *$ & DMSU_55 & 0.278357 & 0.253755 & 0.2727 & \\
\hline DCR_2 & 0.787547 & 0.274664 & 0.0042 & $* * *$ & DMSU_56 & 2.04339 & 0.255261 & $<0.0001$ & $* * *$ \\
\hline DCR_3 & 0.719892 & 0.273762 & 0.0086 & $* * *$ & DMSU_57 & 1.38677 & 0.255132 & $<0.0001$ & $* * *$ \\
\hline DCR_4 & 0.575407 & 0.274636 & 0.0362 & $* *$ & DMSU_58 & 0.377450 & 0.250979 & 0.1327 & \\
\hline DCR_5 & 0.512315 & 0.274421 & 0.0620 & $*$ & DMSU_59 & 0.0181159 & 0.255475 & 0.9435 & \\
\hline DCR_6 & 0.370946 & 0.274390 & 0.1765 & & DMSU_60 & 1.00813 & 0.255053 & $<0.0001$ & $* * *$ \\
\hline DCR_7 & 0.531424 & 0.274369 & 0.0528 & $*$ & DMSU_61 & 1.74726 & 0.255161 & $<0.0001$ & $* * *$ \\
\hline DCR_8 & 0.155427 & 0.274326 & 0.5710 & & DMSU_62 & 1.20687 & 0.280459 & $<0.0001$ & $* * *$ \\
\hline DCR_9 & -0.0586522 & 0.274376 & 0.8307 & & DMSU_63 & 1.48780 & 0.254790 & $<0.0001$ & $* * *$ \\
\hline DCR_10 & -0.109136 & 0.274491 & 0.6909 & & DMSU_64 & 1.67995 & 0.255189 & $<0.0001$ & $* * *$ \\
\hline DMSU_0 & 0.273984 & 0.275824 & 0.3206 & & DMSU_65 & 1.54968 & 0.254829 & $<0.0001$ & $* * *$ \\
\hline DMSU_1 & 1.58494 & 0.281850 & $<0.0001$ & $* * *$ & DMSU_66 & 1.01283 & 0.254563 & $<0.0001$ & $* * *$ \\
\hline DMSU_2 & 3.59121 & 0.380378 & $<0.0001$ & $* * *$ & DMSU_67 & 1.02449 & 0.256490 & $<0.0001$ & $* * *$ \\
\hline DMSU_3 & 3.01793 & 0.459784 & $<0.0001$ & $* * *$ & DMSU_68 & 1.23388 & 0.254946 & $<0.0001$ & $* * *$ \\
\hline DMSU_4 & 3.60222 & 0.278706 & $<0.0001$ & $* * *$ & DMSU_69 & 1.57403 & 0.254929 & $<0.0001$ & $* * *$ \\
\hline DMSU_5 & 1.64856 & 0.259804 & $<0.0001$ & $* * *$ & DMSU_70 & 1.11830 & 0.255006 & $<0.0001$ & $* * *$ \\
\hline DMSU_6 & 3.13873 & 0.307616 & $<0.0001$ & $* * *$ & DMSU_71 & 1.51508 & 0.254863 & $<0.0001$ & $* * *$ \\
\hline DMSU_7 & 2.86052 & 0.448642 & $<0.0001$ & $* * *$ & DMSU_72 & 0.694851 & 0.254627 & 0.0064 & $* * *$ \\
\hline DMSU_8 & 3.92183 & 0.291390 & $<0.0001$ & $* * *$ & DMSU_73 & 2.35029 & 0.255569 & $<0.0001$ & $* * *$ \\
\hline DMSU_9 & 2.11593 & 0.319558 & $<0.0001$ & $* * *$ & DMSU_74 & 0.954120 & 0.258169 & 0.0002 & $* * *$ \\
\hline DMSU_10 & 0.229665 & 0.253992 & 0.3659 & & DMSU_75 & 1.08893 & 0.259736 & $<0.0001$ & $* * *$ \\
\hline DMSU_11 & 2.46133 & 0.263227 & $<0.0001$ & $* * *$ & DMSU_76 & 0.548207 & 0.256534 & 0.0326 & $* *$ \\
\hline DMSU_12 & 2.04548 & 0.271220 & $<0.0001$ & $* * *$ & DMSU_77 & 0.524899 & 0.256162 & 0.0405 & $* *$ \\
\hline DMSU_13 & 1.03592 & 0.352703 & 0.0033 & $* * *$ & DMSU_78 & 0.572397 & 0.256349 & 0.0256 & $* *$ \\
\hline DMSU_14 & 2.11452 & 0.262582 & $<0.0001$ & $* * *$ & DMSU_79 & 0.526319 & 0.255695 & 0.0396 & $* *$ \\
\hline DMSU_15 & 1.62999 & 0.256533 & $<0.0001$ & $* * *$ & DMSU_80 & 0.522300 & 0.253556 & 0.0394 & $* *$ \\
\hline DMSU_16 & 2.20873 & 0.350617 & $<0.0001$ & $* * *$ & DMSU_81 & 0.398045 & 0.252281 & 0.1147 & \\
\hline DMSU_17 & 8.40978 & 0.353731 & $<0.0001$ & $* * *$ & DMSU_82 & 0.505987 & 0.252336 & 0.0450 & $* *$ \\
\hline DMSU_18 & 7.12758 & 0.293024 & $<0.0001$ & $* * *$ & DMSU_83 & 0.404866 & 0.251368 & 0.1073 & \\
\hline DMSU_19 & 7.51274 & 0.282336 & $<0.0001$ & $* * *$ & DMSU_84 & 0.497964 & 0.252021 & 0.0482 & $* *$ \\
\hline DMSU_20 & 4.74388 & 0.712638 & $<0.0001$ & $* * *$ & DMSU_85 & -0.840999 & 0.260954 & 0.0013 & $* * *$ \\
\hline DMSU_21 & 2.26367 & 0.258026 & $<0.0001$ & $* * *$ & DMSU_86 & 0.634968 & 0.283676 & 0.0252 & $* *$ \\
\hline DMSU_22 & 6.60540 & 0.318575 & $<0.0001$ & $* * *$ & DMSU_87 & 0.599492 & 0.254829 & 0.0187 & $* *$ \\
\hline DMSU_23 & 6.15624 & 0.321609 & $<0.0001$ & $* * *$ & DMSU_88 & 0.871991 & 0.254881 & 0.0006 & $* * *$ \\
\hline DMSU_24 & 4.10048 & 0.285756 & $<0.0001$ & $* * *$ & DMSU_89 & -0.462615 & 0.256211 & 0.0710 & $*$ \\
\hline DMSU_25 & 2.33203 & 0.263150 & $<0.0001$ & $* * *$ & DMSU_90 & 0.648241 & 0.256743 & 0.0116 & $* *$ \\
\hline DMSU_26 & 4.71511 & 0.495561 & $<0.0001$ & $* * *$ & DMSU_91 & -0.458028 & 0.257438 & 0.0753 & $*$ \\
\hline DMSU_27 & 1.68118 & 0.256967 & $<0.0001$ & $* * *$ & DMSU_92 & 0.473570 & 0.253210 & 0.0615 & $*$ \\
\hline DMSU_28 & 1.32429 & 0.341899 & 0.0001 & $* * *$ & DMSU_93 & 0.439748 & 0.253006 & 0.0822 & $*$ \\
\hline DMSU_29 & 2.46557 & 0.256538 & $<0.0001$ & $* * *$ & DMSU_94 & -0.498469 & 0.256558 & 0.0521 & * \\
\hline
\end{tabular}




\begin{tabular}{|c|c|c|c|c|c|c|c|c|c|}
\hline Variable & Coefficient & Std. Error & $\mathrm{p}$-value & & Variable & Coefficient & Std. Error & $\mathrm{p}$-value & \\
\hline DMSU_30 & 0.831240 & 0.257288 & 0.0012 & $* * *$ & DMSU_95 & -0.653017 & 0.263316 & 0.0132 & $* *$ \\
\hline DMSU_31 & 0.480275 & 0.258016 & 0.0627 & $*$ & DMSU_96 & -1.14786 & 0.388011 & 0.0031 & $* * *$ \\
\hline DMSU_32 & 2.13631 & 0.586746 & 0.0003 & $* * *$ & DMSU_97 & 0.377172 & 0.252515 & 0.1353 & \\
\hline DMSU_33 & 1.28017 & 0.304029 & $<0.0001$ & $* * *$ & DMSU_98 & -1.28297 & 0.280482 & $<0.0001$ & $* * *$ \\
\hline DMSU_34 & 1.95204 & 0.264221 & $<0.0001$ & $* * *$ & DSLO_1 & 1.01628 & 0.285753 & 0.0004 & $* * *$ \\
\hline DMSU_35 & 1.82340 & 0.260757 & $<0.0001$ & $* * *$ & DSLO_2 & 0.713259 & 0.284436 & 0.0122 & $* *$ \\
\hline DMSU_36 & 7.22291 & 0.319211 & $<0.0001$ & $* * *$ & DSLO_3 & 0.255734 & 0.284427 & 0.3686 & \\
\hline DMSU_37 & 6.86877 & 0.323146 & $<0.0001$ & $* * *$ & DSLO_4 & -0.0270943 & 0.220376 & 0.9022 & \\
\hline DMSU_38 & 2.50761 & 0.292711 & $<0.0001$ & $* * *$ & DSLO_5 & -0.0407938 & 0.220897 & 0.8535 & \\
\hline DMSU_39 & 6.28432 & 0.311240 & $<0.0001$ & $* * *$ & DEXP_0 & 0.0699582 & 0.0258514 & 0.0068 & $* * *$ \\
\hline DMSU_40 & 2.15023 & 0.516784 & $<0.0001$ & $* * *$ & DEXP_1 & 0.0247056 & 0.00528908 & $<0.0001$ & $* * *$ \\
\hline DMSU_41 & 4.16279 & 0.332904 & $<0.0001$ & $* * *$ & DSKE_0 & 0.479573 & 0.210750 & 0.0229 & $* *$ \\
\hline DMSU_42 & 1.98763 & 0.410479 & $<0.0001$ & $* * *$ & DSKE_1 & 0.282111 & 0.210642 & 0.1805 & \\
\hline DMSU_43 & 3.65198 & 0.271980 & $<0.0001$ & $* * *$ & DSKE_2 & 0.159178 & 0.210739 & 0.4501 & \\
\hline DMSU_44 & 5.20199 & 0.285828 & $<0.0001$ & $* * *$ & DSKE_3 & -0.0785973 & 0.198651 & 0.6924 & \\
\hline DMSU_45 & 3.61415 & 0.354733 & $<0.0001$ & $* * *$ & DSKE_4 & -0.106279 & 0.199808 & 0.5948 & \\
\hline DMSU_46 & 3.93287 & 0.301842 & $<0.0001$ & $* * *$ & DSD_0 & 0.113839 & 0.180591 & 0.5285 & \\
\hline DMSU_47 & 1.65288 & 0.260320 & $<0.0001$ & $* * *$ & DSD_1 & -0.138220 & 0.180686 & 0.4443 & \\
\hline DMSU_48 & 3.32327 & 0.258634 & $<0.0001$ & $* * *$ & DSD_2 & -0.321215 & 0.178753 & 0.0724 & $*$ \\
\hline DMSU_49 & 3.22231 & 0.268525 & $<0.0001$ & $* * *$ & DTEX_1 & 0.000250466 & 0.0127444 & 0.9843 & \\
\hline DMSU_50 & 2.46940 & 0.255635 & $<0.0001$ & $* * *$ & DTEX_2 & -0.00689195 & 0.00575191 & 0.2309 & \\
\hline DMSU_51 & 1.78073 & 0.257473 & $<0.0001$ & $* * *$ & DTEX_3 & -0.00770175 & 0.00737167 & 0.2962 & \\
\hline DMSU_52 & 2.50630 & 0.265988 & $<0.0001$ & $* * *$ & DTEX_4 & 0.000491450 & 0.0123988 & 0.9684 & \\
\hline DMSU_53 & 1.36483 & 0.303720 & $<0.0001$ & $* * *$ & & & & & \\
\hline
\end{tabular}

Source: author's estimate, model was tested for multicollinearity by Farrar-Glauber test with negative result Note: ***, **, * indicate the level of significance 1\%, 5\%, 10\%, omitted due to exact collinearity: DMSU_99 DSLO_6 DEXP_3 DSKE_5 DSD_3 DTEX_5

it indicates the model's relatively good statistical properties. According to the quantified adjusted $\mathrm{R}^{2}$ at a level of 0.967 , it is possible to conclude that the model has a high explanatory ability, or more precisely it can be stated that that almost $97 \%$ of land price variability is explained by the used variables, which is a better result than expected with regard to the dummy character of the explanatory factors. At the same time, the verification of the model's statistical significance also provides a positive result, as the performed F-test confirms a high statistical conclusiveness. Both comprehensive outputs provide support for a positive evaluation of the conceived model, which is also supported by the significance of most of the estimated soil characteristic parameters (see below), which is the basis for the sufficient robustness/applicability of the achieved land price model.

If we pay attention to the evaluation of the subparameter estimate (see Tab. IV), then it is first appropriate to state that, of the total of 129 estimated parameters, most (specifically 80) are highly significant, i.e. at a significance level of 0.01 and better. A further 23 parameters are statistically significant at a significance level of at least 0.1, i.e. only 26 estimated parameters are not evaluated as conclusive. During a more detailed look at the table of results from the given output, it

V: Statistical characteristics of estimated model

\begin{tabular}{llll}
\hline \multicolumn{1}{c}{ Sum squared resid } & 23089.28 & S.E. of regression & 1.838228 \\
\cline { 4 - 5 } R-squared & 0.967693 & Adjusted R-squared & 0.967088 \\
F $(129,6833)$ & 1586.584 & P-value (F) & 0.000000 \\
\hline
\end{tabular}

Source: author's work 
is possible to state that the factors of worse climatic regions (more precisely DCR_6, 8-10, representing climatic regions with a high ESEU code value, i.e. in particular cooler and more humid regions), minimally represented soil unit subtypes (in particular DMSU_54,55 and 58,59, i.e. eroded brown earth), poor slope factors (DSLO_3-5), all other characteristics with the exception of best skeletality level (DSKE_1-4) and also two soil profile depth levels (DSD_0-1) are not statistically significant for the derived land price. According to the statistical significance of the estimated parameters, it is then evident that, in the estimated model, all of the granularity characteristics are completely statistically insignificant. Overall, therefore, from a statistical perspective, it can be stated that the conclusive determinants for land price are mainly soil unit type, partly climate region characteristics (in particular for climatically favourable regions), land exposure, and ultimately only the best values from the perspective of slope and skeletality.

During a factually logical analysis of the estimated parameters (while respecting statistical significance and the conditions of ceteris paribus), it is necessary to evaluate the factors separately. The effect of the climatic region fulfils all general prerequisites, i.e. an increase in climatic region level brings about an increase in price, whereby the two best regions even bring about a price increase of more than one unit (i.e. specifically in the DCR_0 region, the price will be higher by $1.2 \mathrm{Sk} / \mathrm{m}^{2}$ and in the DCR_1 region by $1.03 \mathrm{Sk} / \mathrm{m}^{2}$, c.p.). Towards the worse climatic regions, the intensity of the effect on land price decreases. If the insignificance of the given parameters was hypothetically neglected, then the two worst climatic regions would actually reduce the price. A number of studies that point to the influence of temperature and precipitation on agricultural production have reached similar results (e.g. Bindi and Olesen, 2011). For countries in central and northern Europe, an increase in temperature has a positive effect on the per hectare yields of crops such as wheat and maize, which is positively reflected in an increase in land prices (King et al., 2018).

The effect of soil units in the model is probably once again fully in concord with factually logical assumptions. The vast majority of soil units imply a positive increase in price, with the exception of soils that are not agriculturally usable and soils with specific properties (e.g. DMSU_90, 94-98, i.e. gleys, peats and lithosols with a high skeletality). The biggest price increase is brought about by the variables DMSU_17-19 (increase of approximately 8.4, 7.12 or $7.5 \mathrm{Sk} / \mathrm{m}^{2}$, c.p.), which represent the economically best chernozem-type soils, DMSU_22,23 (increase of 6.6 or $6.16 \mathrm{Sk} / \mathrm{m}^{2}$, c.p.), which are so-called phaeozems, and DMSU_37,39 (increase of 6.9 or $6.3 \mathrm{Sk} / \mathrm{m}^{2}$, c.p.), which represent chernozems on loess. Furthermore, it can be generally stated that, in the direction of less economically efficient soils types, the intensity of the effect on land price decreases, which fully confirms the model's basic assumptions, and proves the importance of soil quality from the perspective of soil types.

Slope, as the next assessed determinant, once again provides results consistent with general assumptions. Land with zero or little slope brings about a significant price increase - DSLO_1 increases the price by $1.02 \mathrm{SK} / \mathrm{m}^{2}$, c.p., and DSLO_1 by $0.7 \mathrm{SK} / \mathrm{m}^{2}$, c.p. The remaining soils, with greater slopes, do not have a significant effect on land price; nevertheless, purely hypothetically, the effect decreases, and in the case of the greatest slope there would even be a reduction of the price. Schmidtner et al. (2015) come to similar conclusions in their study, stating that a lower slope increases the price of agricultural land or its rental prices.

A statistically significant determinant is another ESEU characteristic - exposure. Based on the limited variability of the data in the sample and the dummy variable mechanism, only two types can be evaluated - both of the variables DEXP_0 and DEXP_1, representing flat land or a slight southern exposure, have a positive effect on land price; nevertheless, in comparison with previous characteristics, there is usually lower intensity here (change of 0.07 or $0.02 \mathrm{Sk} / \mathrm{m}^{2}$, c.p.) which probably also corresponds to the real conditions of the land price evaluation system.

Skeletality is another estimate determinant, where however a conclusive variable is only DSKE_0, bringing about a positive change in price of $0.48 \mathrm{Sk} / \mathrm{m}^{2}$, c.p. Other characteristics are inconclusive, but once again, purely hypothetically, the direction of the effect is in accordance with logical assumptions, because as a result of higher skeletality the effect would decrease or change to negative.

Soil profile depth is an almost insignificant factor, which is also very problematic in terms of data - the variability of the phenomenon is minimal, and only one code characteristic predominates. The estimate is considerably affected by the afore-mentioned aspects, and therefore it is not completely relevant to evaluate it. Completely hypothetically, it may be possible to use the model to point out a decreasing effect in the direction of a smaller profile theoretically, only a profile with a depth of $60 \mathrm{~cm}$ or more would cause a positive change in price.

The last evaluated aspect was granularity, which is a specific determinant in the ESEU system in the Slovak Republic. However, the estimate of the model shows that this characteristic is completely statistically insignificant for determining land price, and even the estimates of the parameters themselves are close to zero; i.e. from this perspective, the effect of granularity can be neglected, which is probably only evidenced by the auxiliary character.

Overall, it can be stated that the results are probably completely consistent with the model's 
economic assumptions. Characteristics of land located in warm climatic regions, with valuable chernozem-like soil and a slight slope, manifest themselves as significant and positively intensive factors. The decomposition and evaluation of detailed soil units is then the subject of further research activities.

In the case of the comparison of the results of the effect of individual input factors on land price in the Czech Republic and Slovakia, it can be stated that the results in some findings differ. Depending on the input of individual factors, the econometric model used for the ESEU valuation system shows very good values, which is evident primarily from the indicator $\mathrm{R}^{2}$ at a level of 0.967. It can therefore be stated that almost $97 \%$ of land price variability is explained by the used variables. Similar $\mathrm{R}^{2}$ indicator values were also achieved in the case of the Czech Republic. In this case, the $\mathrm{R}^{2}$ was 0.95. The complete model for the Czech Republic is detailed in the publication Slaboch and Čechura (2020).

When comparing climatic regions, climatic region 3, which is defined as warm and slightly humid, fares best under the conditions in the Czech Republic. Compared to climatic region 0, 1 or 2 , it differs primarily by higher precipitation (it offers higher moisture certainty), which has a positive effect on the size of the overall production. Other climatic regions then fall, according to characteristics, under slightly warm to cool, and have a negative effect on ESEU price. From the results for Slovakia, a decreasing trend of the intensity of the effect of this factor on ESEU price is evident. This trend corresponds to the characteristics of climatic regions, where there is essentially a gradual decrease in the number of days with temperature above $5^{\circ} \mathrm{C}$, as well as the decreasing irrigation indicator in individual climatic regions in the summer months. When comparing the influence of the climatic region on the price of individual ESEU in the conditions of the Czech Republic and the Slovak Republic, it can be said that the decreasing average temperature of the climatic region has a negative effect on the price of land, all other factors being ceteris paribus. In Slovakia, climate region 1 and 2 (very warm and warm lowland regions) have the highest impact, where this classification increases the price by 1.2 and $1 \mathrm{SK} / \mathrm{m}^{2}$ respectively. Climate region 3 (warm, humid) has a similar intensity in the Czech Republic, increasing the price by $1.4 \mathrm{CZK} / \mathrm{m}^{2}$. Another important factor affecting ESEU price is the main soil unit (MSU). In this case, the results of the effect of the MSU are very similar in both systems. It is mainly chernozems and phaeozems that have a positive effect on price. On the contrary, an exception are agriculturally unusable soils, or soils with specific properties - mainly gleys, peats etc. In the case of the Czech Republic, these specific MSU have a significant negative effect on the final price of ESEU. When evaluating the effect of soil profile depth and skeletality, the different significance of this factor between the Czech Republic and Slovakia is evident. In the Czech Republic, this factor is very significant and has a high effect intensity, in particular in the case of shallow soils with a medium to high skeletality. On the contrary, in the case of Slovakia, this factor is not statistically significant, nor does it have a very intensive effect on ESEU price. However, the direction of the skeletonisation effect is in line with the logical assumptions that are also fulfilled in the case of the Czech Republic. Soils with high skeletonisation and low soil depth (less than $30 / 60 \mathrm{~cm}$ ) also have a significantly lower price. Similar results can be observed in the study by O'Donoghue et al. (2015), where the authors point out that the price increases with higher soil quality. However, the effect of exposure and slope is statistically significant in the case of Slovakia, and this also applies for the Czech Republic. Increasing slope has a negative effect on the price of the given ESEU, primarily by the lower or more demanding use of these soils for agricultural purposes. A comparison of the results of econometric models determining the effect of individual separated factors on the resulting ESEU price shows individual concords in generally accepted effect assumptions. At the same time, these models can be used to estimate the price of newlycreated ESEUs, or during the revaluation of existing ESEU codes.

\section{CONCLUSION}

The aim of the performed study is to evaluate the effect of the applied land valuation system on the price of land, and as a consequence of the implied links to compare the valuation of soil units in the Slovak and Czech Republic.

From the results, it is evident that, in the case of Slovakia, ESEU valuation is mainly affected by climatic region and main soil unit, as the dominant factor in the size of the final agricultural production. The high intensity of these variables on the price of the given ESEU is evident here. Of the main soil units, chernozems and phaeozems on loess have the greatest effect on price. The dominant effect of main soil units on price is also assumed by Džatko and Sobocká et al. (2009), who state that main soil units are decisive during valuation, as they have the greatest effect on production capacity and value of costs. From the perspective of other factors input into the ESEU, it is evident that the direction of the effect is logical in terms of connection to price, but the effect intensity is not high. Of these 
factors, only land slope has a high significance. Another change in the ESEU system is the addition of a numerical representation of granularity. The model shows this factor to be completely statistically insignificant for setting land price, and even the parameter estimates themselves are close to zero. The results of this model can be applied in future research regarding the relationship between land quality and value, mainly for real estate tax purposes. At the same time, ESEU valuation also comes into play for the purposes of subsidy titles for agricultural land, or during land consolidation. This research only relates to agricultural land outside the municipality's built-up area. Another possibility for future research is a more detailed evaluation of main soil units according to basic characteristics such as water retention, humus content, proportion of carbonates, $\mathrm{pH}$, infiltration capacity, porousness etc. The ESEU system is unique in Europe, mainly by its detail, which is given by comprehensive soil research. From this perspective, it is an excellent tool, particularly for fiscal purposes, which however lags behind reality due to climate change, which further underlines the missing socioeconomic dimension of land, which is included in the valuation system in other parts of the EU. Therefore, it needs to be updated, in particular in the issues of the definition of climatic regions, water retention, impacts of climate change on final agricultural production, and the mechanisms by which positive externalities emerge within the calculation of the gross annual rent effect. The model can also be applied when adjustments to the basic characteristics of climatic regions are necessary. Due to climate change, there is a gradual increase in average temperatures or a change in the value of average precipitation, which may result in a disparity between the tabulated characteristics and reality. These effects can have a positive or negative impact on agricultural production and, consequently, on the official price of land. In the event of a change in the ESEU code, the new price can be determined by using the shadow prices from the econometric model for the individual input characteristics.

\section{Acknowledgements}

This paper was created within the framework of the project [NAZV QK1920280] - Innovation of bonitation system of agricultural lands (ESEU) for the needs of state administration. Supported by the Ministry of Agriculture of the Czech Republic, program ZEMĚ.

\section{REFERENCES}

BINDI, M. and OLESEN, J. E. 2011. The responses of agriculture in Europe to climate change. Regional Environmental Change, 11(Suppl. 1): 151-158.

BUJNOVSKÝ, R. and VILČEK, J. 2011. Soil degradation and soil value in Slovakia - Two problems with common denominator. Agriculturae Conspectus Scientificus, 76(1): 9-14.

DIRGASOVÁ, K., BANDLEROVÁ, A. and LAZÍKOVÁ, J. 2017. Factors affecting the price of agricultural land in Slovakia. Journal of Central European Agriculture, 18(2): 291-304.

DŽATKO, M., SOBOCKÁ, J. et al. 2009. An innovated guide for the evaluation and evaluation of agricultural land in Slovakia [in Slovak: Inovovaná príručka pre bonitáciu a hodnotenie polnohospodárskych pôd Slovenska]. Bratislave: VÚPOP Bratislava.

KILIĆ, J., ROGULJ, K. and JAJAC, N. 2019. Fuzzy expert system for land valuation in land consolidation processes. Croatian Operational Research Review, 10(1): 89-103.

KING, M., ALTDORFF, D., LI, P., GALAGEDARA, L. et al. 2018. Northward shift of the agricultural climate

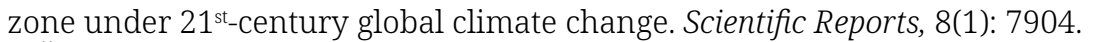

KLEČKA, M. et al. 1984. Bonitation of Czechoslovak agricultural Lands and directions of their use - definition and mapping of evalued soil-ecological units - Czechoslovakia [in Czech: Bonitace čs. zemědělských půd a směry jejich využití - vymezení a mapování bonitovaných půdně-ekologických jednotek - ČSSR]. Praha-Bratislava.

LINKEŠ, V., PESTÚN V. and DŽATKO, M. 1996. Manual for the use of maps of evalued soil-ecological units. Handbook for the evaluation of agricultural land [in Slovak: Príručka pre použivanie máp bonitovaných pôdno-ekologických jednotiek. Príručka pre bonitáciu polnohospodárskych pôd]. Bratislava: VúPÚ Bratislava.

O'DONOGHUE, C., LOEZ, J., O'NEILL, S. et al. 2015. A hedonic price model of self-assessed agricultural land values. In: The spatial dimension in analyzing the linkages between agricultural, rural development and the environment. EAAE $150^{\text {th }}$ Seminar. October 22-23, 2015. Edinburgh, Scotland.

MAŠAT, K. NĚMEČEK, J. and TOMIŠKA, Z. 2002. Methodology of delimitation and mapping of evaluated soil ecological units [in Czech: Metodika vymezováni a mapování bonitovaných pưdně ekologických jednotek]. Praha: Výzkumný ústav meliorací a ochrany půdy VúMOP. 
MP SR. 2021. Vyhláška MP SR č. 38/2005 Z. z. Ministerstvo pôdohospodárstva a rozvoja vidieka SR. Available at: https://www.mpsr.sk/vyhlaska-mp-sr-c-38-2005-z-z/29-23-29-1834 [Accessed: 2021, April 21].

MŽP. 2020. Definice půdy. Praha: Ministerstvo životního prostředí. Available at: https://www.mzp.cz/ cz/definice_pudy [Accessed: 2020, April 19].

NĚMEC, J. 2001. Bonitace a oceňováni zemědělské půdy České republiky. Praha: Výzkumný ústav zemědělské ekonomiky.

NIGMANN, T., DAX, T. and HOVORKA, G. 2018. Applying a social-ecological approach to enhancing provision of public goods through agriculture and forestry activities across the European Union. Studies in Agricultural Economics, 120(1): 1-7.

SCHMIDTNER, E., DABBERT, S. and LIPPERT, C. 2015. Do different measurements of soil quality influence the results of a Ricardian analysis? - A case study on the effects of climate change on German agriculture. German Journal of Agricultural Economics, 64(2): 89-106.

SCHNEIDER, U. A., HAVLÍK, P., SCHMID, E. et al. 2011. Impacts of population growth, economic development, and technical change on global food production and consumption. Agricultural Systems, 104(2): 204-215.

SLABOCH, J. and ČECHURA, L. 2020. Land Pricing Model: Price Re-evaluation Due to the Erosion and Climate Change Effects. AGRIS on-line Papers in Economics and Informatics, 12(4): 111-121.

VÚMOP. 2020. eKatalog BPEJ. Výzkumný ústav meliorací a ochrany půdy. [Online]. Available at: https://bpej.vumop.cz/ [Accessed: 2020, April 24].

Contact information

Josef Slaboch: jslaboch@pef.czu.cz (corresponding author) 